\title{
Evaluation of new maize single and three way crosses for earliness and grain yield over three locations
}

\author{
S.M. Abo El-Haress \\ Maize Research Department, Field Crops Research Institute, ARC, Egypt
}

\begin{abstract}
New 17 yellow inbred lines of maize were mated to the two early testers; inbred line SK11 and SC173 at Sakha Agricultural Research Station in 2012 growing season. The resulting 17 single crosses, 17 three way crosses and two commercial hybrids SC162 and TWC352 were evaluated at three locations i.e. Sakha, Nubaria and Sids stations in 2013 growing season. Data were collected for days to 50\% silking, plant height and grain yield. Analysis of variance revealed the mean squares due to locations (Loc.), crosses (Cr.) and $\mathrm{Cr}$ x Loc. interaction were highly significant for all of studied traits. Mean square due to lines $(\mathrm{L})$, tester $(\mathrm{T}), \mathrm{L} \times \mathrm{T}$ and their interaction with locations were significant or highly significant for all traits. The additive gene effects were most responsible for controlling the inheritance of all traits except for grain yield. The best parental inbred lines which showed desirable GCA effects were SK5056/52 for earliness, SK5062/55 for plant height and SK5038/41 for grain yield. Tester SC173 was the best combiner for all traits except grain yield, SCSK5038/41 x SK11, TWCSK5066/58 x SC173 which were stable for grain yield, outyield and earliness than checks. These two crosses were selected for advanced testing in maize breeding program as early maturing crosses and of high yielding ability.
\end{abstract}

Key words: combining ability - earliness - yellow maize - genotype x location interaction

\section{Introduction}

The national maize breeding program in Egypt is adopting the policy of producing high yielding single and three way crosses and could to be early of maturity. However the earlier hybrids were desirable for specific cropping sequence, intercropping and reduce using water compared to late maturity hybrids. Days to $50 \%$ silking is a highly heritable trait and responds to selection for earliness (Troyer and Brown 1976). When selection for a trait, the expected response depends on the amount of additive genetic variance. The additive genetic variance is the fixable portion of genetic variability (Hallauer and Miranda, 1988) for days to 50\% silking, it is attributed to additive gene effects, therefore, we can depend on silking date as a good and simple index for earliness in maize, a positive correlation has been reported between silking date and grain yield and plant height by Troyer and Brown (1972). The new maize inbred lines could be tested by Line $\mathrm{x}$ Tester Methods to classify them and estimates their general combining ability effects. Hallauer and Miranda (1981), and Menz et al. (1999) reported that the suitable tester should be based on simple of using, ability to classify of lines and maximizing genetic gain. Russell and Eberhart (1975), Darrah (1985)and Horner et al. (1989) suggested that the inbred lines can be used as a tester. Also, El-Ghawas (1963), Castellanos et al. (1998) and Mosa (2010) used single cross as a tester in their investigations.

The objectives of this study were to estimate combining ability effects, determine single and three way crosses for high yielding and earliness and determine stable superior hybrids for grain yield.

\section{Materials and methods}

New seventeen yellow maize inbred lines developed at Sakha Agricultural Research Station (Table 1) were crossed to two early testers i.e. inbred line SK11 and SC173 in 2012 growing season at Sakha station.

The resulting 17 single crosses and 17 three way crosses and two commercial hybrids (SC162, TWC352) were evaluated at Sakha, Nubaria and Sids Experimental Stations. The experimental design was randomized complete block design with four replications.

Plot size was one row of $6 \mathrm{~m}$ long and $80 \mathrm{~cm}$ apart. Planting was in hills at $25 \mathrm{~cm}$ apart. All of the required cultural practices were applied as recommended at the proper time. Data were taken on silking date (number of days from planting to 50\% emergence silking), plant height $(\mathrm{cm})$, and grain yield (ardab/fed.) adjusted based on shelling percent at $15.5 \%$ moisture content.

The combined analysis was done after test of homogeneity of error mean squares for the three locations, according to Steel and Torrie (1980). When differences among top crosses were found significant, line $\mathrm{x}$ tester analysis as outline by Singh and Chaudary (1999) was done.

Stability parameters for grain yield were worked out as suggested by Eberhart and Russel (1996). The coefficient of determination $\left(\mathrm{R}^{2}\right)$ was computed according to Pinthus (1973). 
Table 1. Pedigree and source of the seventeen yellow maize inbred lines and two testers.

\begin{tabular}{ll}
\hline Pedigree & Sources \\
\hline SK5038/41 & Pop. (DMY5001/218-1-1-2-1-1 x Com21 \\
SK5043/43 & Pop (Sku-10 x Comp21) \\
SK5044/44 & Pop (SK6241 x Comp21) \\
SK5045/46 & Pop (SK7070/9-2-2-1-1-9 x Comp21) \\
SK5046/47 & Pop (SK7070/9-2-2-1-1-9 x Comp21) \\
SK5046/48 & Pop (SK7070/9-2-2-1-1-9 x Comp21) \\
SK5046/49 & Pop (SK7070/9-2-2-1-1-9 x Comp21) \\
SK5054/50 & I.Y.309 \\
SK5056/51 & I.Y.398 \\
SK5056/52 & I.Y.398 \\
SK5056/53 & I.Y.398 \\
SK5061/54 & SC162 \\
SK5062/55 & SC166 \\
SK5064/56 & Pop. (Exp.B.9/2005-102) \\
SK5066/57 & Pop. (Exp. B. 9/2005-108) \\
SK5066/58 & Pop. (Exp. B. 9/2005-108) \\
SK5067/59 & Pop. (Exp. B. 9/2005-109) \\
\hline SK11 & Gm1021 x Sd318 \\
SC173 & GZ666 x GZ647 \\
\hline
\end{tabular}

\section{Results and discussion}

Combined analyses of variance of 36 entries for the three traits across in three locations are shown in Table 2. Results in revealed that the differences between three locations (Loc) were highly significant for all studied traits. Also, the entries mean squares were highly significant for all traits. The mean squares and the variance due to the interaction of entries with the locations were highly significant for all traits. Meaning that the tested entries varied from each to other and showed differential performance in the testing locations.

Table 2. Analysis of variance of 36 entries for three traits across three locations.

\begin{tabular}{lcccc}
\hline S.O.V. & d.f & Days to 50\% silking & Plant height (cm) & Grain yield (ard. /fed.) \\
\hline Locations (Loc) & 2 & $2969.05^{* *}$ & $157851.2^{* *}$ & $1889.805^{* *}$ \\
Rep/Loc & 9 & 15.357 & 554.826 & 34.564 \\
Entries & 35 & $46.628^{* *}$ & $1921.27^{* *}$ & $83.342^{* *}$ \\
E x Loc & 70 & $5.641^{* *}$ & $244.220^{* *}$ & $41.515^{* *}$ \\
Error & 315 & 2.320 & 141.811 & 9.547 \\
\hline
\end{tabular}

** significant at 0.01 level of probability

The grand mean of locations for the three traits are presented in Table (3). Sakha location gave the highest mean for all of studied traits except for days to $50 \%$ silking. Meanwhile, Sids location had the lowest values for all traits except for days to $50 \%$ silking which Nubaria location gave the lowest mean for days to 50\% silking. Frey (1964) and Frey and Maldonado (1967) defined the stressed environment as the one in which mean performance for a certain attribute is low and that stress for one traits does not mean stress for all traits under study.

Table 3. Grand means of locations for the three traits.

\begin{tabular}{|c|c|c|c|c|}
\hline Location & Trait & Days to $50 \%$ silking & Plant height $(\mathrm{cm})$ & Grain yield (ardab/fed.) \\
\hline Sakha & & $56.796 \mathrm{~b}$ & 281.276 & $32.776 \mathrm{a}$ \\
\hline Sids & & $60.033 \mathrm{a}$ & $224.375 \mathrm{~b}$ & $25.830 \mathrm{c}$ \\
\hline Nubaria & & $51.270 \mathrm{c}$ & $226.612 b$ & $28.244 \mathrm{~b}$ \\
\hline C.V.\% & & 2.72 & 4.88 & 10.67 \\
\hline
\end{tabular}

Mean performance of the 36 entries (17 single cross, 17 three way crosses) and 2 check hybrids for three traits across three locations are presented in Table (4).

For days to $50 \%$ silking 17 single crosses were earlier than SC162, the best crosses from them were
SK5054/50 x SK11, SK5056/52 x SK11 and SK5062/55 x SK11, while 11 three way crosses were earlier than check TWC 352. The best crosses from them were SK5054/50 x SC173, SK5056/52 x SC173 and SK5062/55 x SC173. These results exhibited that the inbred lines SK5054/50, 
SK5056/52 and SK5062/55 gave the best single and three way crosses for earliness. Hence these inbred lines and their single and three way crosses could be utilized for the breeding programs as early maturing crosses where their harvesting ranged from 95 to 100 days from planting. The 16 single crosses were shorter than SC162. The best crosses from them were SK5044/44 x SK11 and SK5062/55 x SK11. The three crosses of TWC were shortly for plant height than TWC352, the best crosses from them SK5044/44 x SC173 and SK5062/55 x SC173. Results showed that inbred lines SK5044/44 and SK5062/55 gave shortest single and three way crosses for plant height.
For grain yield, single cross SK5038/41 x SK11 was significantly outyielded than SC162, while three way cross SK5054/50 x SC173 was higher than TWC 352. Also, three way crosses SK5038/41 x SC173, SK5061/54 x SC173 and SK5066/58 x SC173 were not significantly outyielded than TWC 352. The above results exhibited that TWCSK5054/50 x SC173 (53.07 days and $32.75 \mathrm{ard} / \mathrm{fed}$.), SK5066/58 x SC173 (55.83 days and $31.72 \mathrm{ard} / \mathrm{fed}$.$) and$ SCSK5038/41 x SK11 (58.38 days and 34.97 ard/fed.) could be used in maize breeding program as early maturing crosses and high yielding ability.

Table 4. Mean performance of 36 entries (17 single crosses (SC), 17 three way crosses (TWC) and 2 checks) for three traits across three locations

\begin{tabular}{|c|c|c|c|c|c|c|}
\hline \multirow{2}{*}{$\begin{array}{l}\text { Trait } \\
\text { Inbreeding line }\end{array}$} & \multicolumn{2}{|c|}{ Days to $50 \%$ silking } & \multicolumn{2}{|c|}{ Plant height $(\mathrm{cm})$} & \multicolumn{2}{|c|}{ Grain yield (ardab/fed) } \\
\hline & SK11 & SC173 & SK11 & SC173 & SK11 & SC173 \\
\hline SK5038/41 & $58.58 * *$ & 57.50 & $251.66^{* *}$ & 255.83 & $34.97 *$ & 31.76 \\
\hline SK5043/43 & $57.16 * *$ & 56.16 & $242.58 * *$ & 240.91 & 28.54 & 27.02 \\
\hline SK5044/44 & $55.41 * *$ & $54.41 * *$ & $226.25^{* *}$ & $230.41 * *$ & 26.29 & 28.26 \\
\hline SK5045/46 & $54.83 * *$ & $54.41 * *$ & $249.50 * *$ & 238.83 & 28.62 & 28.82 \\
\hline SK5046/47 & $55.66 * *$ & $53.58 * *$ & $246.00 * *$ & 236.16 & 26.23 & 26.24 \\
\hline SK5046/48 & $55.58 * *$ & $53.08 * *$ & $240.66 * *$ & $231.50 * *$ & 26.21 & 27.48 \\
\hline SK5046/49 & $59.25 *$ & $54.91 *$ & $240.91 * *$ & 242.16 & 30.59 & 28.69 \\
\hline SK5054/50 & $54.25 * *$ & $53.08 * *$ & $249.33 * *$ & 239.50 & 28.57 & $32.75 *$ \\
\hline SK5056/51 & $55.75 * *$ & $54.08 * *$ & $242.33 * *$ & 241.08 & 26.85 & 29.73 \\
\hline SK5056/52 & $53.00 * *$ & $53.00 * *$ & $251.41 * *$ & 240.66 & 28.75 & 27.60 \\
\hline SK5056/53 & $58.75 * *$ & 57.50 & 274.41 & 259.00 & 32.12 & 24.41 \\
\hline SK5061/54 & $57.66 * *$ & 56.08 & $244.41 * *$ & 250.83 & 31.22 & 30.32 \\
\hline SK5062/55 & $54.50 * *$ & $53.58 * *$ & $211.41 * *$ & $209.91 * *$ & 31.15 & 28.30 \\
\hline SK5064/56 & $55.91 * *$ & 56.83 & $246.41 * *$ & 251.00 & 29.11 & 29.49 \\
\hline SK5066/57 & $58.83 * *$ & 56.58 & $253.33 * *$ & 247.75 & 28.32 & 20.69 \\
\hline SK5066/58 & $57.83 * *$ & $55.83 *$ & $255.33^{* *}$ & 255.33 & 27.34 & 31.72 \\
\hline SK5067/59 & $56.50 * *$ & $55.00 * *$ & $230.33^{* *}$ & 237.58 & 30.46 & 27.23 \\
\hline Check SC162 & 60.83 & - & 267.75 & - & 32.50 & - \\
\hline TWC352 & - & 57.08 & - & 245.08 & - & 30.18 \\
\hline LSD 0.05 & 1.22 & 1.22 & 9.52 & 9.52 & 2.47 & 2.47 \\
\hline 0.01 & 1.66 & 1.66 & 12.54 & 12.54 & 3.26 & 3.26 \\
\hline
\end{tabular}

*,** significant or highly significant than the check.

Mean squares of line $\mathrm{x}$ tester analysis for the 34 new crosses for three traits across three locations are presented in Table 5. Significant or highly significant differences were detected among lines (L), tester (T) and $\mathrm{L} \times \mathrm{T}$ interaction and their interaction with locations ( $\mathrm{L} \times$ Loc, $\mathrm{T} \times \mathrm{Loc}$ and $\mathrm{L} \times \mathrm{T} \times \mathrm{Loc}$ ) for all of the studied traits meaning that the both inbred lines and tester behaved differently in their crosses over three locations and were differently in location to another. The obtained results are in harmony with those conclusions reached by Nawar and El-Hosary (1984), El-Shenawy (2005), Mosa et al. (2008) and Mosa (2010).

Table 5.Mean squares due to liens (L), testers (T) and $\mathrm{L} x \mathrm{~T}$ and their interaction with location (Loc) for studied three traits.

\begin{tabular}{lcccc}
\hline S.O.V. & d.f & Days to 50\% silking & Plant height $(\mathrm{cm})$ & Grain yield (ardab/fed.) \\
\hline Line (L) & 16 & $61.823^{* *}$ & $3528.438^{* *}$ & $88.589^{* *}$ \\
Tester T & 1 & $196.297^{* *}$ & $807.539^{*}$ & $74.62^{* *}$ \\
L x T & 16 & $7.896^{* *}$ & $299.487^{* *}$ & $69.47^{* *}$ \\
L x Loc & 32 & $15.311^{* *}$ & $337.06^{* *}$ & $71.74 * *$ \\
T x Loc & 2 & $34.659^{* *}$ & $1907.429^{* *}$ & $170.521^{* *}$ \\
L x T x Loc & 32 & $6.398^{* *}$ & $402.35^{* *}$ & $39.169^{* *}$ \\
Error & 297 & 2.316 & 140.87 & 9.63 \\
\hline
\end{tabular}

*,** significant at 0.05 and 0.01 levels of probability, respectively. 
Estimates of the variance due to general combining ability (GCA), specific combining ability SCA and their interaction with locations for three traits are shown in Table 6.

Table 6.Estimates of the additive gene effects $\left(\mathrm{K}^{2} \mathrm{GCA}\right)$ and the non-additive gene effect $\left(\mathrm{K}^{2} \mathrm{SCA}\right)$ and their interactions with locations for three traits.

\begin{tabular}{lccc}
\hline Genetic components & Days to 50\% silking & Plant height $(\mathrm{cm})$ & Grain yield (ardab/fed.) \\
\hline $\mathrm{K}^{2} \mathrm{GCA}$ & 1.450 & 14.288 & 0.629 \\
$\mathrm{~K}^{2} \mathrm{SCA}$ & 0.465 & 13.218 & 4.980 \\
$\mathrm{~K}^{2} \mathrm{GCA} \times$ Loc & 0.596 & 18.94 & 15.460 \\
$\mathrm{~K}^{2} \mathrm{SCA}$ x Loc & 1.020 & 65.37 & 7.380 \\
\hline
\end{tabular}

The additive gene effects $\left(\mathrm{K}^{2} \mathrm{GCA}\right)$ played an important role more than non-additive gene effects $\left(\mathrm{K}^{2} \mathrm{SCA}\right)$ in the expression of all of studied traits except for grain yield, where non-additive gene effects $\mathrm{K}^{2} \mathrm{SCA}$ were extremely high. These results are in agreement with those obtained by El-Shenawy (2005) for days to $50 \%$ silking, El-Shenawy and Mosa (2005) for grain yield and Mosa (2010) for plant height.

Estimates of $\mathrm{K}^{2} \mathrm{GCA} \times$ Loc were higher than those of $\mathrm{K}^{2} \mathrm{SCA} \times$ Loc for grain yield meaning that the additive components of the genetic variation were more affected by location for grain yield while for days to $50 \%$ silking and plant height showed that, the non-additive gene effects were more interacted with locations. Similar results were obtained by Silva and Hallauer (1975) and Mosa (2010).

Estimates of general combining ability effects of 17 inbred lines for three studied traits across three locations are presented in Table (7). Results showed that eight inbred lines showed significant desirable GCA effects for earliness. The best inbred lines from them were SK5056/52, SK5054/50 and SK5062/55. For plant height four inbred lines exhibited desirable negative GCA effects, the best inbreds from them SK5044/44 and SK5062/55. While the desirable inbred lines for GCA effects for grain yield were SK5038/41, SK5054/50 and SK5061/54.

On the other hand, the heterozygous tester SC173 was the best combiner for days to $50 \%$ silking and plant height, while, the homozygous tester inbred line SK11 was the best for grain yield. El-Ghawas (1963); Sokolov and Kostyuchence (1978), Mosa (2001) and Mosa (2004) found that the cross was the best as tester, while Al-Naggar et al. (1997), Mosa et al. (2004) noticed that inbred lines was good combiner as tester.

Table 7. Estimates of general combining ability effects for the 17 inbred lines and two testers over three locations

\begin{tabular}{lccc}
\hline & Days to 50\% silking & Plant height $(\mathrm{cm})$ & Grain yield (ardab/fed.) \\
\hline SK5038/41 & $2.3088^{* *}$ & $10.6667^{* *}$ & $4.434^{* *}$ \\
SK5043/43 & $0.9338^{* *}$ & -1.3333 & -0.903 \\
SK5044/44 & $-0.8162^{* *}$ & $-14.750^{* *}$ & $-1.411^{*}$ \\
SK5045/46 & $-1.2328^{* *}$ & 1.0833 & 0.042 \\
SK5046/47 & $-1.1078^{* *}$ & -2.000 & $-2.237^{* *}$ \\
SK5046/48 & $-1.3995^{* *}$ & $-7.000^{* *}$ & $-1.821^{* *}$ \\
SK5046/49 & $1.3505^{* *}$ & -1.5417 & 0.957 \\
SK5054/50 & $-2.0662^{* *}$ & 1.3333 & $1.668^{*}$ \\
SK5056/51 & $-0.8162^{* *}$ & -1.3750 & -0.391 \\
SK5056/52 & $-2.7328^{* *}$ & 2.9583 & -0.509 \\
SK5056/53 & $2.3922^{* *}$ & $23.6250^{* *}$ & -0.413 \\
SK5061/54 & $1.1422^{* *}$ & 4.5417 & $2.085^{* *}$ \\
SK5062/55 & $-1.6912^{* *}$ & $-32.4167 * *$ & 1.040 \\
SK5064/56 & $0.6422^{*}$ & $5.6250^{*}$ & 0.619 \\
SK5066/57 & $1.9755^{* *}$ & $7.4583^{* *}$ & $-4.172^{* *}$ \\
SK5066/58 & $1.1005^{* *}$ & $12.250^{* *}$ & 0.849 \\
SK5067/59 & 0.0172 & $-9.125^{* *}$ & 0.163 \\
\hline LSD g 0.05 & 0.608 & 4.748 & 1.241 \\
0.01 & 0.829 & 6.468 & 1.691 \\
\hline TeSter Sk-11 & $0.693^{* *}$ & $1.50^{*}$ & $0.427^{*}$ \\
Tester SC-173 & $-0.693^{* *}$ & $-1.50^{*}$ & $-0.427^{*}$ \\
\hline LSD gi 0.05 & 0.20 & 1.50 & 0.425 \\
0.01 & 0.23 & 1.97 & 0.580 \\
\hline
\end{tabular}


Estimates of specific combining ability effects of the 34 crosses across the three grown locations are presented in Table (8). The crosses SK5046/49 x SC173 and SK5064/56 x SK11 showed significant desirable SCA for days to $50 \%$ silking, while the crosses SK5054/50 x SC173,SK5056/51 x SC173, SK5061/53 x SK11, SK5064/56 x SK11 and SK5066/58 x SC173 exhibited significant positive SCA for grain yield. These results suggest use of these crosses in maize breeding program to produce high yielding hybrids.

Stability parameters of the 36 crosses evaluated at three locations are presented in Table (9). According to the definition of Eberhart and Russel (1966) cross with high mean (than grand mean) combined with a regression coefficient equal to the unity (bi=1) or not significant and small deviations from regression $\left(\mathrm{S}^{2} \mathrm{~d}=0\right)$ or not significant is considered to be stable, also Pinthus (1973) reported that the hybrids may considered to be stable when coefficient of determination $\left(\mathrm{R}^{2}\right)$ is higher than $80 \%$. Therefore, five crosses SK54038/41 x SK11, SK55038/41 x SC173, SK5064/56 x SK11, SK5064/56 x SC173 and SK5066/58 x SC173 were stable for grain yield.

Generally, single cross SK5038/41 x SK11 and three way cross SK5066/58 x SC173 were the best crosses in this study because of its stable, outyield than checks in addition significant for earliness than checks. These two crosses were selected for advanced testing in maize breeding program.

Table 8. Estimates of specific combining ability effects for the 34 new crosses across three locations.

\begin{tabular}{|c|c|c|c|}
\hline Cross & Days to $50 \%$ silking & Plant height $(\mathrm{cm})$ & Grain yield (ardab/fed.) \\
\hline SK5038/41 x SK11 & -0.15196 & -3.490 & 0.926 \\
\hline SK5038/41 x SC173 & 0.15196 & 3.490 & -0.926 \\
\hline SK5043/43 x SK11 & -0.19363 & -0.573 & 0.330 \\
\hline SK5043/43 x SC173 & 0.19363 & 0.573 & -0.330 \\
\hline SK5044/44 x SK11 & -0.19363 & -3.490 & -1.411 \\
\hline SK5044/44 x SC173 & 0.19363 & 3.490 & 1.411 \\
\hline SK5045/46 x SK11 & -0.61029 & 3.926 & -0.526 \\
\hline SK5045/46 x SC173 & 0.61029 & -3.926 & 0.526 \\
\hline SK5046/47 x SK11 & 0.34804 & 3.509 & -0.638 \\
\hline SK5046/47 x SC173 & -0.34804 & -3.509 & 0.638 \\
\hline SK5046/48 x SK11 & 0.55637 & 3.176 & -1.049 \\
\hline SK5046/48 x SC173 & -0.55637 & -3.176 & 1.049 \\
\hline SK5046/49 x SK11 & $1.47304 * *$ & -2.031 & 0.517 \\
\hline SK5046/49 x SC173 & $-1.47304 * *$ & 2.031 & -0.517 \\
\hline SK5054/50 x SK11 & -0.11029 & 3.509 & $-2.215^{*}$ \\
\hline SK5054/50 x SC173 & 0.11029 & -3.509 & $2.215^{*}$ \\
\hline SK5056/51 x SK11 & 0.13971 & -0.781 & $-1.870 *$ \\
\hline SK5056/51 x SC173 & -0.13971 & 0.781 & $1.870 *$ \\
\hline SK5056/52 x SK11 & -0.69363 & 3.968 & 0.146 \\
\hline SK5056/52 x SC173 & 0.69363 & -3.968 & -0.146 \\
\hline SK5056/53 x SK11 & -0.6863 & 6.301 & $3.427 * *$ \\
\hline SK5056/53 x SC173 & 0.06863 & -6.301 & $-3.427 * *$ \\
\hline SK5061/54 x SK11 & 0.09804 & -4.615 & 0.021 \\
\hline SK5061/54 x SC173 & -0.09804 & 4.615 & -0.021 \\
\hline SK5062/55 x SK11 & -0.23529 & -0.656 & 0.995 \\
\hline SK5062/55 x SC173 & 0.23529 & 0.656 & -0.995 \\
\hline SK5064/56 x SK11 & $-0.15196 *$ & -3.698 & -0.617 \\
\hline SK5064/56 x SC173 & $1.15196 *$ & 3.698 & 0.617 \\
\hline SK5066/57 x SK11 & 0.43137 & 1.384 & $3.389 * *$ \\
\hline SK5066/57 x SC173 & -0.43137 & -1.384 & $-3.389 * *$ \\
\hline SK5066/58 x SK11 & 0.30637 & -1.406 & $-2.616^{* *}$ \\
\hline SK5066/58 x SC173 & -0.30637 & 1.406 & $2.616^{* *}$ \\
\hline SK5067/59 x SK11 & 0.05637 & -5.031 & 1.190 \\
\hline SK5067/59 x SC173 & -0.05637 & 5.031 & -1.190 \\
\hline $\mathrm{LSD} \mathrm{S}_{\mathrm{ij}} 0.05$ & 0.861 & 6.715 & 1.755 \\
\hline 0.01 & 1.172 & 9.18 & 2.391 \\
\hline
\end{tabular}


Table 9. Stability parameters of grain yield for crosses evaluated at three locations

\begin{tabular}{|c|c|c|c|c|}
\hline Lines & bi & $\mathrm{S}^{2} \mathrm{di}$ & $\mathrm{R}^{2}$ & $\dot{\bar{x}}$ \\
\hline SK5038/41 x SK11 & 1.099 & -1.72 & 97.30 & 34.976 \\
\hline SK5038/41 x SC173 & 1.940 & 1.10 & 96.237 & 31.767 \\
\hline SK5043/43 x SK11 & $0.392 *$ & $25.9 * *$ & 11.833 & 28.540 \\
\hline SK5043/43 x SC173 & 0.605 & -1.426 & 88.936 & 27.025 \\
\hline SK5044/44 x SK11 & 1.127 & $16.709 * *$ & 62.126 & 26.291 \\
\hline SK5044/44 x SC173 & 0.671 & -0.592 & 85.06 & 28.260 \\
\hline SK5045/46 x SK11 & $0.430 *$ & -2.411 & 96.89 & 28.629 \\
\hline SK5045/46 x SC173 & 0.693 & -2.075 & 96.09 & 28.629 \\
\hline SK5046/47 x SK11 & 0.681 & -2.076 & 95.97 & 26.237 \\
\hline SK5046/47 x SC173 & $0.081 *$ & -2.142 & 28.30 & 26.661 \\
\hline SK5046/48 x SK11 & $0.171 *$ & -2.227 & 68.58 & 26.243 \\
\hline SK5046/48 x SC173 & $0.482 *$ & -1.85 & 97.01 & 27.488 \\
\hline SK5046/49 x SK11 & $2.513 *$ & -1.044 & 99.04 & 30.59 \\
\hline SK5046/49 x SC173 & 0.764 & -0.647 & 88.35 & 28.699 \\
\hline SK5054/50 x SK11 & 0.635 & 2.489 & 99.29 & 28.571 \\
\hline SK5054/50 x SC173 & $0.079 *$ & -2.516 & 77.88 & 32.143 \\
\hline SK5056/51 x SK11 & $1.636^{*}$ & -2.308 & 99.62 & 26.853 \\
\hline SK5056/51 x SC173 & 0.884 & 6.784 & 67.53 & 29.738 \\
\hline SK5056/52 x SK11 & $0.499 *$ & 4.002 & 48.57 & 28.750 \\
\hline SK5056/52 x SC173 & $0.165^{*}$ & 1.856 & 13.30 & 27.603 \\
\hline SK5056/53 x SK11 & $2.735^{*}$ & 0.28 & 98.49 & 32.129 \\
\hline SK5056/53 x SC173 & 0.873 & 3.191 & 76.47 & 24.42 \\
\hline SK5061/54 x SK11 & $2.078 *$ & -0.751 & 98.34 & 31.22 \\
\hline SK5061/54 x SC173 & 0.991 & $19.57 * *$ & 52.45 & 30.32 \\
\hline SK5062/55 x SK11 & $0.534 *$ & -1.378 & 85.72 & 31.152 \\
\hline SK5062/55 x SC173 & $0.419 *$ & 7.727 & 29.80 & 28.304 \\
\hline SK5064/56 x SK11 & 0.919 & 2.242 & 98.50 & 29.118 \\
\hline SK5064/56 x SC173 & 1.195 & -2.459 & 99.71 & 29.490 \\
\hline SK5066/57 x SK11 & 1.011 & 2.548 & 99.95 & 28.382 \\
\hline SK5066/57 x SC173 & $0.054 *$ & 6.711 & 0.78 & 20.690 \\
\hline SK5066/58 x SK11 & $2.110 *$ & 4.878 & 93.7 & 27.340 \\
\hline SK5066/58 x SC173 & 1.312 & -0.868 & 96.20 & 31.720 \\
\hline SK5067/59 x SK11 & $1.174 *$ & 0.820 & 90.50 & 30.468 \\
\hline SK5067/59 x SC173 & 0.775 & -1.639 & 94.19 & 27.230 \\
\hline Check SC162 & $3.297 *$ & 30.046 & 89.23 & 32.50 \\
\hline Check TWC352 & $0.528 *$ & 4.256 & 50.43 & 30.18 \\
\hline
\end{tabular}

\section{References}

Al-Naggar, A.M.; H.Y. El-Sherbieny and A.A. Mahmoud (1997). Effectiveness of inbred, single crosses and population as testers for combining ability in maize. Egypt. J. Plant Breed., 1: 35-46.

Castellanos, J.s; A.R. Hallauer and H.S. Crodova (1998). Relative performance of testers to identify elite of corn (Zea mays L.). Maydica, 43: 217-226.

Darrah, L.L. (1985). Evaluation of population improvement in the Kenya maize breeding methods study. P. 160-175. Into feed ourselves. Proc. First Eastern Central and Southern Africa Regional Workshop Lusaka Zambia, GiMMYT Mexico, D.F.

Eberhart, S.A. and W.A. Russell (1966). Stability parameters for comparing varieties. Crop Sci., 6: $36-40$.
El-Ghawas, M.T. (1963). The relative efficiency of certain open pollinated varieties, single and double crosses as testers in evaluating the combining ability of maize inbred lines in top cross. J. Agric. Res. Alex. 11: 115-130.

El-Shenawy, A.A. (2005). Estimation of genetic and environment parameters for new white inbred lines of maize (Zea mays L.). J. Agric. res., Tanta Univ., 31:647-662.

El-Shenawy, A.A. and H.E. Mosa (2005). Evaluation of new single and three way maize crosses for resistance to downy mildew diseases and grain yield under different environments. Alex. J. Agric. Res., 50: 35-43.

Frey, K.J. (1964). Adaptation reaction of oat strains selected under stress and non-stress environmental conditions. Crop Sci. 4: 55-58.

Frey, K.J. and M. Maldonado (1967). Relative productivity of homogenous and heterogenous oat cultivation optimum and sub-optimum environments. Crop Sci., 7: 532-535. 
Hallauer, A.R. and J.B. Miranda (1981). Quantitative Genetics in maize breeding. Iowa State Univ. Press, Ames., USA.

Hallauer, A.R. and J.B. Miranda (1988). Quantitative Genetics in maize breeding $2^{\text {nd }}$ ed. Iowa State Univ. Press., Ames., 468 p.

Horner, E.S.; E. Magloire and J.A. Morera (1989). Comparison of selection for $\mathrm{S}_{2}$ progeny test cross performance for population improvement in maize. Crop Sci., 29: 868-874.

Menz, M.A.; A.r. Hallauer and W.A. Russell (1999). Comparative response of two reciprocal recurrent selection methods in BS21 and BS22 maize populations. Crop Sci., 39: 89-97.

Mosa, H.E. (2001). A comparative study of the efficiency of some maize testers for evaluation a number of white maize inbred lines and their combining ability under different environmental condition. Ph.D. Thesis, Fac. Agric., Kafr ElSheikh, Tanta Univ., Egypt.

Mosa, H.E. (2004). Comparison between two types of testers for evaluating new white inbred lines for maize. Annals of Agric. Sci., Moshtohor, 42: 475-487.

Mosa, H.E. (2010). Estimation of combining ability of maize inbred lines using top cross mating design. J. Agric. Kafrelsheikh Univ., 36: 1-16.

Mosa, H.E.; A.A. El-Shenawy and A.A. Motawei (2008). Line $\mathrm{x}$ tester analysis for evaluation of new maize inbred line. J. Agric.Sci. Mansoura Univ., 33: 1-12.

Nawar, A.A. and A.A. El-Hosary (1984). Evaluation of testers for different genetic sources of corn. J. Genet. Cytoc., 13: 227-237.

Pinthus, M.J. (1973). Estimate of genetic values: A proposal method Euphytica, 22: 121-123.

Russell, W.A. and S.A. Eberhart (1975). Hybrid performance of selected maize lines from reciprocal recurrent selection and test cross selection programs. Crop Sci., 15: 1-4.

Silva, J.C. and A.R. Hallauer (1975). Estimation of epistatic variance in Iowa stiff stalk synthetic maize. J. Heredity, 66: 290-296.

Singh, R.K. and B.D. Chaudary (1999). Biometrical Methods in Quantitative Genetic Analysis. Kalyani Publishers Ludhiana.

Sokolov, B.P. and V.I. Kostyuchenko (1978). Choice of testers for the evaluation of combining ability in maize lines in top crosses sel, skokhazyaistvennaya Biolog., 13(1): 44-48.

Steel, R.G.D. and J.H. Torrie (1980). Principles and Procedures of Statistics. A Biometric Approach. $2^{\text {nd }}$ Ed. McGraw Hill, N.Y., USA.

Troyer, A.F. and W.L. Brown (1972). Selection for early flowering in corn. Crop Sci., 12: 301-304.

Troyer, A.F. and W.L. Brown (1976). Selection for early flowering in corn latte synthetics. Crop Sci., 16: 767-772. 


\section{تقييم هجن ذرة شامية فردية وثلاثية جديدة للتبكير والمحصول فى ثلاث مواقع

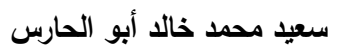

\section{مركز البحوث الزراعية ـ معهُ بحوث المحاصيل الحقلية ـ قسم بحوث الذرة الثامية}

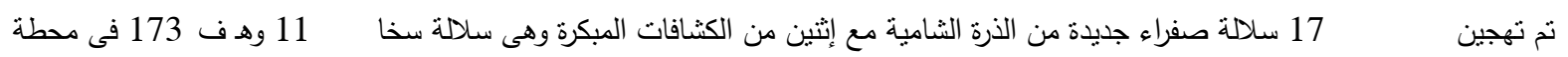

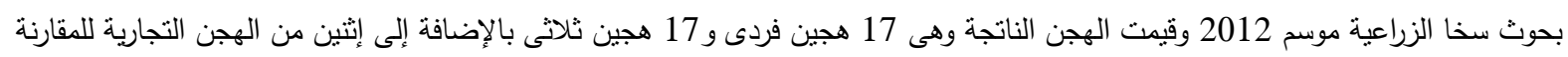

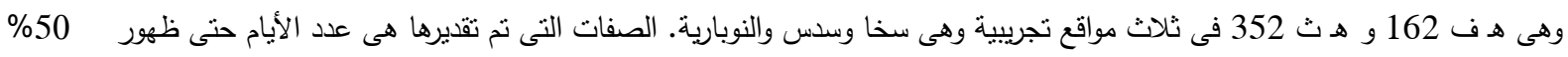

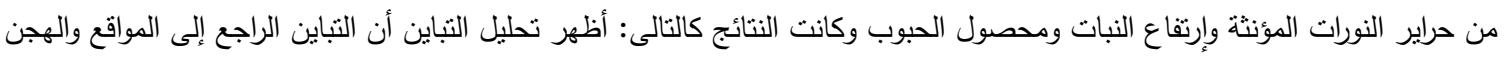

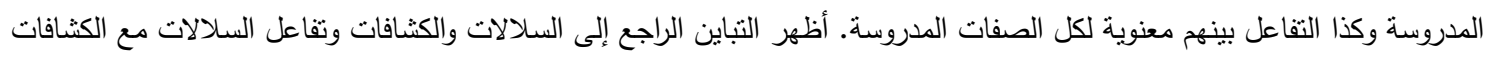

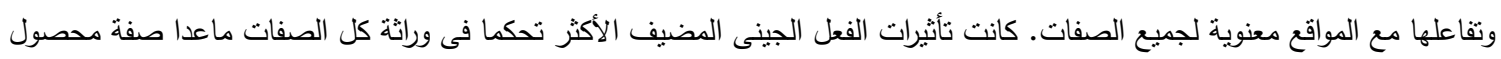

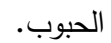

52/5056 لصفة عدد الأيام حتى ظهور 50\% من حرائر النورات المؤنثة أفضل السلالات فى القدرة العامة على الائتلاف هى سخا

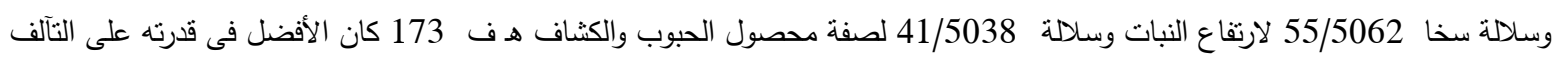
المرغوب لجميع الصفات الدروسة ماعدا صفة محصول الحبوب.

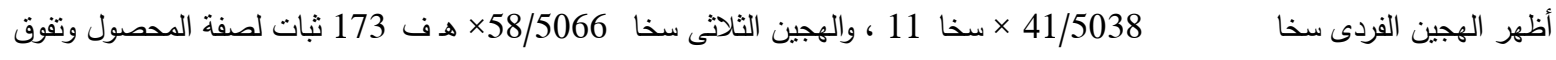
على هجن المقارنة فى التبكير والمحصول وبالتالى يمكن استخدامهما فى الاختبارات المتقدمة فى برنامج التربية. 